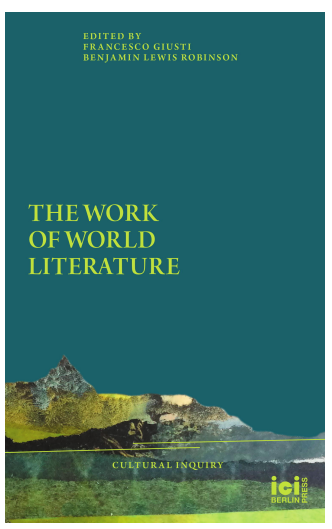

The Work of World Literature, ed. by Francesco Giusti and Benjamin Lewis Robinson, Cultural Inquiry, 19 (Berlin: ICI Berlin Press, 2021), pp. 75-103

\section{FRANCESCO GIUSTI}

\section{Transcontextual Gestures \\ A Lyric Approach to the World of Literature}

\author{
CITE AS:
}

Francesco Giusti, 'Transcontextual Gestures: A Lyric Approach to the World of Literature', in The Work of World Literature, ed. by Francesco Giusti and Benjamin Lewis Robinson, Cultural Inquiry, 19 (Berlin: ICI Berlin Press, 2021), pp. 75103 <https://doi.org/10.37050/ci-19_04>

RIGHTS STATEMENT:

\author{
(C) by the author(s) \\ This work is licensed under a Creative Commons Attribution- \\ ShareAlike 4.0 International License.
}

ABSTRACT: What if one thinks not in terms of shared meanings or contents, but rather in terms of iterable gestures available for reenactment in different times and places in order to conceive of a cross-cultural world of literature? This essay sets out to explore, within the discursive mode of the lyric, whether the notion of gesture could be more helpful than meaning-based translation to account for the transferability of literary texts and for envisioning a form of community based on the shareability of certain gestures. To do so, it will look at how the act-event of reading described by Derek Attridge is processed in two cases in which poems are transferred from an earlier authoritative tradition into a new one.

KEYWORDS: gesture; lyric; transferability; world literature; community; transcontextual; translation; re-enactment 


\title{
Transcontextual Gestures
}

\author{
A Lyric Approach to the World of Literature \\ FRANCESCO GIUSTI
}

TRANSLATABILITY VS TRANSFERABILITY

As a starting point, it would be helpful to distinguish between at least two notions of 'world literature'. The first concerns a contemporary phenomenon, namely, the intense globalization of the production, circulation, and reception of literary texts across languages, cultures, and nations. The second is a methodological turn that intends to renew critical approaches and open up university curricula by giving them a much larger geographical frame going beyond national borders and ideally extending to the entire globe. If the former addresses mainly literature of the current era, the latter could also involve literary works of the distant past. Within these two different notions of world literature, the issue of translation acquires quite different contours. The translation of contemporary literary works 
from one language into another raises the problem of 'untranslatability', which is the conceptual instrument that Emily Apter, for instance, deploys against a 'secure' idea of world literature, and with good reason. ${ }^{1}$ In the second field, untranslatability as usually conceived does not always hold. If one looks at the long history of Western literatures, translation becomes a widespread phenomenon that has less to do with respecting as much as possible the cultural context of the 'original' and its language than with transferring 'something' of a certain literary work from one context to another. Many pre-modern instances of literary translation had little to do with efforts at maintaining the contextual meaning of the 'original', let alone its original letter.

I am interested here in what gets 'translated' in the sense of 'transferred' from the previous literary work into the new one, and above all in what makes that transference possible. Therefore, more than on translatability or untranslatability, I will focus on questions of transcultural and, more specifically, transcontextual transferability. The idea is that the transcontextual - by which I mean both the diachronically transhistorical and the synchronically transcultural - could be grounded in pre-semantic or beyond-semantic recurrent features. ${ }^{2}$ Transferability could

1 Emily Apter, Against World Literature: On the Politics of Untranslatability (London: Verso, 2013).

2 I prefer the term transcontextual to transnational, transregional, and translocal for several reasons. It is not bound to the modern notion of 'nation state' and therefore can be deployed transhistorically; it is not based on geographical spatiality, but can account also for cultural, socio-economic, physical, and temporal differences; and it may help engage with micro-variations, in fact the more flexible notion of context can span from the pole of one's own idioculture to the opposite pole of the global world as a macro-context, and potentially beyond. At least two contexts always interact in the act of reading, the one brought by the literary work, however underdetermined and mediated, and the one 
be seen as a characteristic proper to literature, but not necessarily to one's world. For the approach I intend to pursue here, taking Derek Attridge's theory of the literary as a point of departure, the problem with world literature would not so much be that there is not one 'literature' as that there is not one 'world'. As long as there are singular readers, the world can hardly be one. However, when they put texts to work as literature, their experiences of reading may have something in common.

Each reader's idioculture, to use Attridge's term, combines global and local elements to form a singular arrangement of knowledge, experiences, and feelings. ${ }^{3}$ Theory can describe features of literary texts spread all over the globe, but 'world' is an abstraction deployed by a relatively small community of interpreters. The notion of 'world' is indeed quite problematic even in the current age of the Anthropocene: not all the individual inhabitants of this globe would easily ascribe themselves to the general category of actors on a planetary scale, whatever the action might be. In other words, when 'I' read a novel or a poem, 'I' may be ready to expose myself to the experience of a generalizable use of language, but ' $I$ ' do not necessarily identify with a global, or globalized, reader. 'I' do not immediately transcend my self to become a representative member of a cosmopolitan reading community. Similar considerations may hold for writers too. What if, then, one thinks not in

brought by the reader, and several contexts may intersect in each of them.

3 Derek Attridge, The Work of Literature (Oxford: Oxford University Press, 2015), pp. 60-62. See also Derek Attridge, The Singularity of Literature (London: Routledge, 2004), pp. 21-22 and Francesco Giusti, 'Literature at Work: A Conversation with Derek Attridge', Los Angeles Review of Books, 11 June 2018 <https://lareviewofbooks.org/ article/literature-at-work-a-conversation-with-derek-attridge/> [accessed 23 May 2020]. 
terms of shared meanings or feelings, but rather in terms of re-enacted gestures in order to conceive of a translingual world of literature? ${ }^{4}$

I will not engage here with the first notion of world literature as a set of phenomena in contemporary literary production, but will engage rather with a consequence of the second notion, namely, that there might be describable features recurring across different literary traditions. I intend to focus on gestures that come before the production of in-context meaning and are active at two different levels and at two different removes from it: transcultural gestures and a more basic linguistic gesture. ${ }^{5}$ Therefore, my approach coincides neither with the ideal 'security' of full translatability denounced by Apter nor with the 'radical philology' advocated by John T. Hamilton in opposition to that 'security'. To be clear, I do not want to argue for a sort of anthropological polygenesis (i.e., the same gestures appearing autonomously in different cultures), but rather want to query how and why literary texts work as vehicles for certain gestures (i.e., the ways in which those

4 This approach to world literature distinguishes itself from approaches based on the global circulation and impact of particular literary works: the Epic of Gilgamesh, Dante's Divina Commedia, Shakespeare's plays, Cervantes' Don Quixote, etc. See David Damrosch, What Is World Literature? (Princeton, NJ: Princeton University Press, 2003) and Martin Puchner, The Written World: The Power of Stories to Shape People, History, and Civilization (New York: Random House, 2017).

5 Gesture can be defined in opposition to action as the 'pattern' of an action that has no ends and no meaning in itself, but acquires these when performed in a particular context. Similar notions of gesture associated with a form of community and with literature can be found in Bertolt Brecht, Walter Benjamin, Giorgio Agamben (discussed in the last section), and in Roland Barthes, How to Live Together: Novelistic Simulations of Some Everyday Experience, trans. by Kate Briggs (New York: Columbia University Press, 2012), pp. 133-34.

6 Apter, Against World Literature, pp. 129-130. John T. Hamilton, Security: Politics, Humanity, and the Philology of Care (Princeton, NJ: Princeton University Press, 2013). 
gestures travel along with actual texts). My aim is to explore, within the discursive mode of the lyric, whether these two types of gesture could be more helpful than notions of meaning-based linguistic translation to account for the transferability of literary texts across different contexts and for a conceptualization of world literature. ${ }^{7}$ To do so, I will look at how the act-event described by Attridge - the both active and passive encounter in which readers put a text to work as literature - is processed in the transference of previous poems into new ones. ${ }^{8}$ This approach may also be helpful to minimize the distorting effects of the historicity of the very idea of literature, especially when looking at texts composed before European modernity.

\section{UNNECESSARY TRANSLATIONS}

Let us have a look at the 'birth' of Italian poetry and to the richest manuscript of the so-called Italian 'poetry of the origins', the canzoniere Vaticano Latino 3793, which dates from the end of the thirteenth century, beginning of the fourteenth. The collection is divided into two parts according to metrical genres: the first consists of canzoni, the second of sonnets. In the ordering of the authors, several critics have detected the historiographic intent to trace the 'evolution' of Italian vernacular lyric of the thirteenth century: from the Sicilian School, through the Sicilian-Tuscan poets, up to Dante and the poet known as Dante's Friend. ${ }^{9}$

7 For an approach to the lyric based on classical poetics, see Boris Maslov, 'Lyric Universality', in The Cambridge Companion to World Literature, ed. by Ben Etherington and Jarad Zimbler (Cambridge: Cambridge University Press, 2018), pp. 133-48.

8 Attridge, The Singularity of Literature, p. 26 and note 16; The Work of Literature, pp. 59-60.

9 I canzonieri della lirica italiana delle origini, ed. by Lino Leonardi, 4 vols (Florence: SISMEL-Edizioni del Galluzzo, 2000), i: Il Canzoniere 
The poem that opens the manuscript - and therefore to which a degree of precedence, if not origination, is attributed — is Giacomo da Lentini's (c. 1210-1260) Madonna, dir vo voglio. ${ }^{10}$ Yet, the first two stanzas of this inaugural poem in the chronological order of the canzoniere are actually a 'translation' of an earlier poem, $A$ vos, midontç, written by the Occitan troubadour Folquet de Marselha (c.1155-1231). The first stanza of Folquet's poem reads:
A vos, midontç, voill retrair'en cantan cosi.m destreign Amor[s] e men'a fre vas l'arguogll gran, e no m'aguda re, qe.m mostras on plu merce vos deman; mas tan mi son li consir e l'afan qe viu qant muer per amar finamen. Donc mor e viu? non, mas mos cors cocios mor e reviu de cosir amoros a vos, dompna, c $[\mathrm{e}]$ am tan coralmen; sufretç ab gioi sa vid'al mort cuisen, per qe mal vi la gran beutat de vos. ${ }^{11}$

Vaticano; Roberto Antonelli, 'Canzoniere Vaticano latino 3793', in Letteratura italiana: Le Opere, ed. by Alberto Asor Rosa, 4 vols (Turin: Einaudi, 1992-96), I: Dalle Origini al Cinquecento (1992), pp. 27-44; Roberto Antonelli, I poeti della scuola siciliana, 3 vols (Milan: Arnoldo Mondadori Editore, 2008), I: Giacomo da Lentini, pp. xxvi-xxx.

10 The Sicilian poems are mostly transmitted in three manuscripts produced in Tuscany, a very different context form the court of Frederick II in which they were composed. They underwent a linguistic Tuscanization: 'a sort of translation, of phonic and thus graphic transcoding from the original Sicilian to Tuscan, more or less homogeneous, through which only slight traces of the previous formulation show themselves', Fulvio Delle Donne, La porta del sapere: Cultura alla corte di Federico II di Svevia (Rome: Carocci, 2019), p. 109. As Delle Donne makes clear, this is an 'absolutely common phenomenon' in textual transmission: 'in the Middle Ages, but to a different extent also in the preceding and subsequent epochs, any copyist, while transcribing a text, adapted it to his linguistic code of reference; in other words, he read and automatically "translated" it, adapting its parlance to the orthographic rules $[\ldots]$ ' (p. 109; translation is mine).

11 Folchetto di Marsiglia, Le poesie di Folchetto di Marsiglia, ed. by Paolo Squillacioti (Pisa: Pacini, 1999), p. 414. Trans. by David Murray: 'To 
Giacomo's version of the first stanza reads and looks quite different:

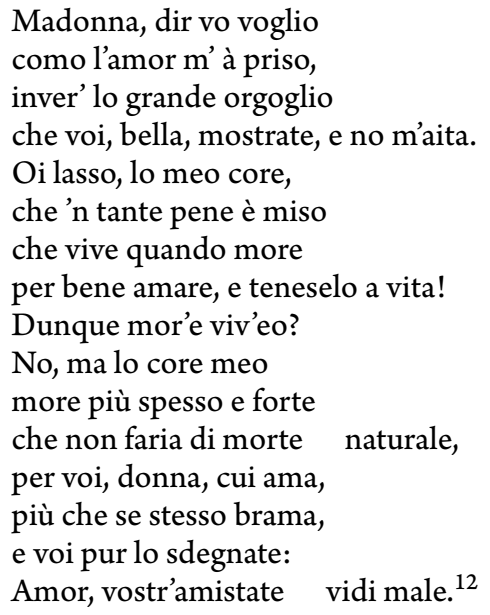

The two poems are not only in different languages, but also have different line-lengths, metrical structures, and rhyme patterns, not to mention Giacomo's adding three

you, madam, I want to relate in song | How Love torments me and directs me | To great pride (and it does not help me) | That you show me there where I ask you for greater mercy, | But so great are my worry and travails | That I live as I die, from loving exquisitely. | So I live and die? No, but my eager heart | Dies and lives again from love's worry | About you, lady, whom I love so deeply; | Accept with joy his life on painful death, | For I ill saw your great beauty', in David Murray, 'Telling the Difference: Linguistic Differentiation and Identity in Guillem de Berguedà, Giacomo da Lentini and Bonifacio Calvo', Zeitschrift für romanische Philologie, 134.2 (2018), pp. 381-403 (p. 389).

12 Roberto Antonelli, I poeti della Scuola siciliana, I, Giacomo da Lentini, pp. 10-14. Trans. by David Murray: 'My lady, I want to say to you | How love has taken me | Towards the great pride | That you, beauty, show, and do not help me, | Alas, my heart, | Which is placed in such pain | That it lives as it dies | From loving well, and keeps itself alive. | So do I live and die? | No, but my heart | Dies more often and more forcefully | Than it would from natural death | From you, lady, whom it loves | And craves more than itself, | And you just disdain it; | Love, I did not see well your friendship', in Murray, 'Telling the Difference', p. 390. 
stanzas to Folquet's two (the only surviving ones for us). They were produced in rather different sociocultural contexts and possibly delivered through diverse media. The troubadour canso was probably performed orally with musical accompaniment in the feudal courts of Provence. The Sicilian canzone was most likely read and circulated among the lettered functionaries of the itinerant imperial court of Frederick II in Southern Italy, where its author worked as an administrative officer (notaro) trained in rhetoric and jurisprudence. ${ }^{13}$ Both lament the pain of unrequited love, but they have quite different meanings in their respective contexts: the former might reflect the conditions and concerns of a feudal society, the latter seems to meditate, with a rather intellectual interest, on the effects of the fire of love on the individual and his language. So, what is it that the two poems share? What allows for this transcontextual re-enactment? Is it only the foundational value ascribed to Provençal poetry by the learned Sicilian poet decades later? Giacomo translates Folquet and appropriates his words. ${ }^{14}$ In this way, not only does he acknowledge the troubadour poet as a predecessor and thus inscribe his own writing in a tradition he himself is tracing, but he also confirms the validity of that speech for an audience that knows the 'original' by introducing contextual differences. There is something in that speech act that is considered still prac-

13 Delle Donne, La porta del sapere, pp. 83-98.

14 Discussing Giacomo's operation, for which he 'was rewarded [...] by the compiler of the Vatican canzoniere with his position at the "start" of the Italian lyric tradition', Murray writes: 'More importantly, Lentini's lexical choices and those of his transmitters gesture at both stages toward the "old" language of poetry, be that Occitan or Sicilian, while simultaneously demonstrating what can be done with the new. Linguistic traits are used to triangulate relationships between connected traditions, and to construct a new literary identity, proving ownership of this new language, counter-intuitively, by drawing attention to its lineage', in Murray, 'Telling the Difference', pp. 392-93. 
ticable in the new context and within the retrospectively traced 'genre'.

Emphasizing the innovations of Madonna, dir vo voglio in comparison to its model, Michelangelo Picone speaks of translatio poesis as a creative operation and concludes his analysis of the changes introduced by Giacomo with these words: 'A simple grammatical change is sufficient to generate a complex cultural transformation. Therefore, it is in the folds of linguistic translation that the seed of the nascent literary tradition hides itself. ${ }^{, 15}$ According to Picone, in Folquet, the 'I' is both alive and dead; in Giacomo, only the heart suffers that paradoxical condition, not the ' $I$ ' in his entirety. In any case, among other revelatory variations (including the Sicilian's reduction of emphasis on physical presence and on the request for mercy as a direct exchange), one could simply note that in Folquet the heart dies and comes back to life ('mos cors cocios | mor e reviu'; my eager heart | dies and lives again; 11. 7-8), in Giacomo it dies repeatedly ('lo core meo | more più spesso'; my heart dies more often; 11. 10-11). Deep down, it is not the 'biography' that is interchangeable, but a certain code, a set of signs that do not yet convey any contextual meaning. They perform an action when enacted in a certain context, but make themselves available for re-enactment and for the production of various meanings in different contexts. The

15 Michelangelo Picone, 'Aspetti della tradizione/traduzione nei poeti siciliani', in Percorsi della lirica duecentesca. Dai siciliani alla 'Vita nova' (Fiesole: Cadmo, 2003), pp. 17-31 (p. 31). Delle Donne speaks of an 'artistic translation' that follows a tradition that 'goes back to the origins of Latin literature, which begins with the translation of the Homeric Odyssey provided by Livius Andronicus', in La porta del sapere, p. 97; translation is mine. See also Roberto Antonelli, ' $\mathrm{L}$ '“invenzione" del sonetto', Cultura neolatina, 47 (1987), pp. 19-59 (p. 25); Furio Brugnolo, 'I siciliani e l'arte dell'imitazione: Giacomo da Lentini, Rinaldo d'Aquino e Iacopo Mostacci 'traduttori' dal provenzale', $\mathrm{La}$ parola del testo, 3 (1999), pp. 45-74 (pp. 45-53). 
code's range of possibilities can be modified in a negotiation between conservation and innovation, but it is not radically alterable, otherwise the enunciation would be unrecognizable for the reader and the enunciated discarded as incomprehensible. The viability of a model is not predicated on biographical identity, but on the recognizability and shareability of the model itself.

The 'origins' of the Italian lyric tradition take place and are made possible by a validation, through re-enactment, of a model offered by troubadour poetry. It is a transfer that shows continuity across languages, time, and space. A similar case is Catullus' translation of Sappho's fragment 31 in his carmen 51: at the 'origins' of Latin love lyric lies the 'translation' with variations of a poem written by a woman in another land more than five centuries earlier. The subject of enunciation inscribes himself, even mentioning his own name and the name of his beloved Lesbia, into the reenactment of the model. The previous poem functions as an offering of potentialities. The re-actualization does not need to be a 'faithful' rendering in another language, that is to say, a translation in the modern sense of the word. Those potentialities can be passed on through the re-enactment of the gesture that opens them up.

From a purely linguistic perspective, Giacomo's translation was probably unnecessary. One can in fact assume that the well-educated poet-officers at the court of Frederick II were perfectly able to understand the Occitan of the original. If such a translation was meant to enlarge the audience, one is compelled to ask: What audience? Whose audience? It may be hard to believe that this translation would have reached a much wider audience outside of the court, but it is the second question that interests me here. The audience supposedly to be enlarged does not seem to 
be Folquet's audience, but rather Giacomo's. More than a linguistic translation in the modern sense of the word, aimed at expanding the readership of Folquet's poem while maintaining as much as possible its 'original' meaning, this operation aims at creating both a new poem and a new poet, and in this way a new poetic tradition, by retrieving the gesture performed and valued in the earlier poem.

If the cultural gesture performable in both contexts is evidently the lament for unrequited love in association with the praise of the beloved, which is the linguistic gesture that can be repeated in diverse contexts and thus allow for this re-enactment? Which linguistic gesture needs a context for each of its performances in order to acquire a meaning, but at the same time is not bound to any historically fixed context? I would suggest that the linguistic gesture that makes such an iterability possible is deixis. In fact, the direct address to the beloved woman (midontç/Madonna, vos/vo) establishes from the outset an open referentiality that leaves the position of the addressee and object of the speech, as much as the position of the speaking 'I', open enough to be fulfilled in different speech contexts. My hypothesis, therefore, is that deixis may be the basic linguistic gesture that characterizes the lyric as a discursive mode.

\section{EACH 'NOW'}

Let us turn to another pair of poems - this time separated by a much longer temporal distance - or rather to one poem caught as it travels from the heart of an ancient empire to the periphery of a modern one: 'Anything Can Happen' by the Irish poet Seamus Heaney and the poem by the Latin poet Horace it re-actualizes (Odes, I, 34). 
These two poems are at the centre of Jahan Ramazani's investigation of the relations between poetry and the news in Poetry and its Others (2013) and they are also mentioned in his illustration of the translocal character of Heaney's poetry in A Transnational Poetics (2009). ${ }^{16}$ Horace's ode I, 34 reads:

\author{
Parcus deorum cultor et infrequens, \\ insanientis dum sapientiae \\ consultus erro, nunc retrorsum \\ vela dare atque iterare cursus \\ cogor relictos. Namque Diespiter \\ igni corusco nubila dividens \\ plerumque, per purum tonantis \\ egit equos volucremque currum, \\ quo bruta tellus et vaga flumina, \\ quo Styx et invisi horrida Taenari \\ sedes Atlanteusque finis \\ concutitur. Valet ima summis \\ mutare et insignem attenuat deus \\ obscura promens: hinc apicem rapax \\ Fortuna cum stridore acuto \\ sustulit, hic posuisse gaudet. ${ }^{17}$
}

16 Jahan Ramazani, A Transnational Poetics (Chicago: University of Chicago Press, 2009), p. 40. 'Neither localist nor universalist, neither nationalist nor vacantly globalist, a translocal poetics highlights the dialogic intersections - sometimes tense and resistant, sometimes openly assimilative - of specific discourses, genres, techniques, and forms of diverse origins. Located in translocation, transnational and crossethnic literary history thus differs from "postnational" or "postethnic" history, in which writers are viewed, when these terms are used most broadly, as floating free in an ambient universe of denationalized, deracialized forms and discourses' (p. 43).

17 'I was a stingy and infrequent worshipper of the gods all the time that I went astray, expert that I was in a mad philosophy. Now I am forced to sail back and repeat my course in the reverse direction. For Jupiter, who normally splits the clouds with his flashing fire, drove his thundering horses and flying chariot across a clear sky. At that the heavy earth and wandering rivers, at that the Styx, and the dreaded abode of hated 
In this ode, Horace allegedly tells of how his certainties as a skeptical Epicurean rationalist were profoundly unsettled by the abrupt occurrence of an unexpected event: a lightning bolt hurled by Jupiter into the clear sky. This is precisely the phenomenon the absence of which had been used by Lucretius to question the general belief that thunderbolts are divine instruments in De rerum natura ('Again, why does he never hurl a bolt upon the earth and sound his thunder from a sky that is completely clear?', vI, 40001). ${ }^{18}$ Now, instead, this exceptional event that shakes the entire world induces the 'I' to ponder, astonished, on the omnipotence of the god and the unpredictable whims of Fortune. It is difficult to say whether this can be considered as a truly autobiographical episode, and it is equally problematic to specify to what extent Horace the poet is really distancing himself from his adherence to Epicurean philosophy. The general sense of the poem, however, is fairly clear: a dismay in the face of incomprehensible forces that humans are unable to explain.

Two thousand years later, Heaney rewrites Horace's ode into a poem first published in the Irish Times on 17 November 2001, under the title 'Horace and the Thunder', and then collected in District and Circle in 2006, under the new title 'Anything Can Happen'. The direct reference to the Latin predecessor is effaced in the collected

Taenarus, and the boundaries marked by Mount Atlas, were shaken. God has the power to cause the highest and the lowest to change places; he makes the illustrious dim and brings the obscure to light. With a piercing scream rapacious Fortune snatches the crown from one head and likes to place it on another', in Horace, Odes and Epodes, ed. and trans. by Niall Rudd (Cambridge, MA: Harvard University Press, 2004), pp. 84-87.

18 Lucretius, On the Nature of Things, trans., with introduction and notes by Martin Ferguson Smith (Indianapolis, IN: Hackett Publishing Company, 2001), p. 189. 
poem: the title, which repeats the opening half-line and the beginning of line eight, is a general statement that summarizes the poem's 'message', perhaps even increasing the distance from the particular event to which the poem 'refers. ${ }^{19}$ Heaney's poem drops Horace's first strophe about the personal turnaround, and the 'now' (nunc; 1.3) of the change of mind, which follows the weather phenomenon in Horace, becomes the 'now' (1. 3) in which the event takes place. Heaney takes up the contrast between the usual phenomenon of lightning and the exceptional event that Jupiter makes happen, the unpredictable reversals that the god and Fortune bring about, and Mount Atlas, which marks the limits of the known Western world, becomes 'the Atlantic shore itself' (1. 7). Yet Heaney superimposes an intensely visual memory of the attack on the Twin Towers of 11 September 2001 on Horace's poem, especially in the catastrophic imagery of the added final strophe:

Ground gives. The heaven's weight

Lifts up off Atlas like a kettle-lid.

Capstones shift, nothing resettles right.

Telluric ash and fire-spores boil away.

Even though linked to an event very far from the 'original' one, this rewriting appears surprisingly close to Horace's words (particularly striking is the retention of Roman divinities in a context so charged with religious tension). An easy projection of the Epicurean vulgate on a materialistic West in pursuance of secularization is probably to be resisted, but the two poems undoubtedly evoke a similar reaction, that is, an unexpected dismay that overwhelms the experiencing subject and reveals the vanity of the convictions cultivated up to that point. The ' $I$ ' has to face the 
shocking irruption of unfathomable forces in their private life as well as on the stage of History. Heaney repeats with some variations the expressions pronounced two millennia earlier by his predecessor, letting their significance resonate with the new context. The words from the past return to be re-enacted in different circumstances, as if themselves independent of any temporal situation, establishing a kind of present outside of chronological time that speaks to every present as a discourse addressing itself specifically to it.

I am not interested here in the possible proximity of the abrupt fall of Horace's Epicurean illusions to the historical breakpoint Heaney is facing. What interests me is how those very words can be re-enacted in different cultural contexts. Heaney turns Horace's more I-centered meditative speech into a piece of wisdom - 'anything can happen' - addressed to a 'you' which, by mentioning ancient gods, seems to allude to its transhistorical validity. What in Horace is a personal crisis in the subject's belief becomes, in Heaney's poem, a sudden realization of a shared condition in the face of a historical catastrophe. The 'content-message' of Horace's ode may be suitable to the new context; yet, what is it that allows for the repetition of those words and figures?

Commenting on this pair of poems and comparing the durability of poetry with the rapid obsolescence of the news, Ramazani writes:

The 'just now' of Horace's poem ('nunc') is renewed, doubling as the now of the ancient past and the now of the immediate present, unlike the once-only 'now' of the news. To reiterate and adapt Benjamin, poetry 'does not expend itself. It preserves and concentrates its strength and is capable of releasing it even after a long time.' [...] One part of our experience of Heaney's poem is the power of its compact and eerie evocation of 
the 9/11 attacks; another is our wonder at poetry's transhistorical durability and transnational adaptability $[\ldots]$. Poet and reader encounter the 'news event' through a cross-historical and crosscultural detour into literary antiquity, responding simultaneously to an ancient text and to current reality. ${ }^{20}$

For Ramazani, in order to understand Heaney's poem, the reader needs 'to know something not only about the Twin Tower attacks but also about Horace, Jupiter, the River Styx, and classical Fortune; you have to have some context for the poem's literariness and difficulty, its classical mythology, and elevated diction'. In other words, '[t] he poem acknowledges its deep embeddedness within literary tradition, instead of presenting itself as a history-free report of current reality.' This 'intensity' is achieved by 'deploying a variety of poetic resources' including syntactic complexity, apostrophe, enjambment, mixed registers, chiasmus, metaphor, simile, and alliteration. 'As memorable speech that remembers prior memorable speech, and yet that also evokes contemporary reality, the poem freely translates Horace to point up references to 9/11, dropping Horace's first stanza and adding a new final stanza. ${ }^{21}$

Ramazani's analysis is undoubtedly accurate, but Heaney's poem only 'evokes' the 9/11 attacks or contemporary reality more generally insofar as it is read by readers who, having experienced those globally broadcast images and knowing the context of the poem's production, project that information onto the text. In the same way that the Latin poem does not necessarily evoke

\footnotetext{
20 Jahan Ramazani, Poetry and its Others: News, Prayer, Song, and the Dialogue of Genres (Chicago: University of Chicago Press, 2014), pp. 68-69.

21 Ibid., pp. 70-71.
} 
Epicureanism nor even the Roman Empire, if the reader does not know anything about the poet Horace. Therefore, what is needed for the reader's response may not be, in the first place, 'some context for the poem's literariness and difficulty' nor the poem's 'deep embeddedness within literary tradition', but rather the recognition of a certain use of language which does exactly the opposite, that is, it subtracts the utterance from contextual referentiality. Horace's 'nunc' can be doubled in Heaney's 'just now' because there is nothing within the text that fulfils that act of temporal deixis, just as there is no individuated subject to whom the ' $\mathrm{I}$ ' in Horace and the 'you' in Heaney refer. Before any production of meaning and any supplement of contextual information, the 'transhistorical durability and transnational adaptability' of Horace's lyric poem, as much as Heaney's, is based on its open referentiality. The words of Horace's ode are applicable to a different external context because the text does not provide any context for the utterance within itself. The news, on the contrary, seems to rely heavily on that immediate external referentiality whose transience makes it short-lived.

A lyric poem does not take the reader to an alternative space nor, as Jonathan Culler maintains following Käte Hamburger, does it project a fictional world; ${ }^{22}$ it rather needs a larger world in which to happen as a performance, a world which it can point to. ${ }^{23}$ The gesture underlying the text is not embedded in a world that the text itself brings forth as usually happens in narratives. If it had its own

22 Jonathan Culler, Theory of the Lyric (Cambridge, MA: Harvard University Press, 2015), pp. 106-08.

23 On lyric indexicality see Daniel Tiffany, 'Lyric Poetry and Poetics', in Oxford Research Encyclopedia of Literature, 30 April 2020, Oxford University Press <https://doi.org/10.1093/acrefore/ 9780190201098.013.1111>. 
fictional world, the gesture could have been a fully accomplished action and it could be more easily transmitted in association with the meaning it would have acquired in that world. In contrast, this peculiar situation allows for a quite radical re-semantization of the gesture underlying the text in each of its contexts of reading and re-writing. Finally, the gesture readers recognize while reading a poem is likely to carry with it previous or subsequent instantiations of that gesture and this coalescence or accretion plays a crucial role in the act-event of reading and in the process of recognition.

\section{GESTURAL COMMUNITIES}

In 'What is Epic Theater?' (1939), Walter Benjamin famously describes Bertolt Brecht's epic theatre on the basis of a notion of gesture defined in opposition to the unity of action that Aristotle requires for tragedy in his Poetics. For Benjamin, gesture interrupts action and plot. As Samuel Weber explains, gesture involves not the fulfilment or realization of an intention or of an expectation but rather its disruption and suspension. ${ }^{24}$ Gesture also needs to be quotable and, as Benjamin affirms, '[q] uoting a text entails interrupting its context. ${ }^{, 25}$ According to Weber, gesture gives form because, while interrupting an 'ongoing sequence', it 'fixes it by enclosing it in a relatively determined space, one with a discernible "beginning" and "end." But at the same time, the closure brought about by gesture remains caught up in that from which it has partially extric-

24 Samuel Weber, Benjamin's -abilities (Cambridge, MA: Harvard University Press, 2008), p. 98.

25 Walter Benjamin, 'What is Epic Theatre? (II)', trans. by Harry Zohn, in his Selected Writings, 4 vols (Cambridge, MA: Harvard University Press, 1996-2003), IV: 1938-1940, ed. by Howard Eiland and Michael W. Jennings (2003), pp. 302-09 (p. 305). 
ated itself: in the "living flux" of a certain temporality. ${ }^{26}$ Benjamin ascribes a dialectical dimension to the tension embodied in gesture, and Weber comments,

'gesture' does not merely interrupt something external to it: the expressive intentionality of an action, the teleology of a narrative, or the causal necessity or probability of a sequence of events. It does all of this, but it also does something more: insofar as it is citable, it interrupts itself, and indeed, only 'is' in its possibility of becoming other, of being transported elsewhere. ${ }^{27}$

The theatrical space, from which discourse is directed at others and even at the future, is a virtual medium that 'causes the borders of all interiority - and be they those of the interval itself - to tremble.' This 'trembling' exposes both spectators and actors 'to the afterthought that, after all, they share the same trembling space of singularity. It is a space not of Einfühlung but of Exponierung, of exposure to the possibility of separation and detachment. ${ }^{, 28}$

Benjamin's reflections bear a resemblance to Rainer Maria Rilke's lyric meditation on the 'ununterbrochene Nachricht' (uninterrupted message; 1. 60) that calls upon the 'now' from the past and his exhortation to a trembling endurance in the first of the Duineser Elegien, written in 1912 (11. 49-53):

Sollen nicht endlich uns diese ältesten Schmerzen fruchtbarer werden? Ist es nicht Zeit, daß wir liebend uns vom Geliebten befrein und es bebend bestehn: wie der Pfeil die Sehne besteht, um gesammelt im Absprung mehr zu sein als er selbst. Denn Bleiben ist nirgends. ${ }^{29}$

\footnotetext{
26 Weber, Benjamin's-abilities, p. 100.

27 Ibid., p. 103.

28 Ibid., p. 108.

29 Rainer Maria Rilke, Werke, ed. by Manfred Engel, Ulrich Fülleborn, Horst Nalewski, and August Stahl, 4 vols (Frankfurt a.M.: Insel, 1996),
} 
What Rilke seems to be proposing here, by way of exhortation, is the formation of a 'we' (wir) based on the repetition of the gesture of praising the beloved, which involves a suspension of knowledge ('Beginn | immer von neuem die nie zu erreichende Preisung'; Begin, always anew, the unattainable praise; 11.39-40). This repeatability interrupts the particular individuality of each lover and of each beloved to inscribe each of them into a transtemporal citable gesture. At the same time, however, that potential gesture is 'fruitful' inasmuch as it enables the praising of each individual. In Rilke's elegy, the 'I' and the 'you' are brought together in a collective 'we' by this shareable gesture. Different individuals can enact it and in this way participate in a form of transtemporal choral community. Therefore, what can be shared - both synchronically and diachronically — is neither a particular object of love nor a specific text, but rather the gesture of praising and thus a certain modality of loving. ${ }^{30}$

Yet, following Brecht, Benjamin is well aware that gestures cannot be re-enacted a-historically. ${ }^{31}$ Their viability depends on the social, cultural, and political conditions of the poets and their epoch, and different gestures contribute to the formation of different communities. In his 'Commentary on Poems by Brecht', written between the

II: Gedichte 1910 bis 1926, ed. by Manfred Engel and Ulrich Fülleborn, pp. 201-04. 'Shall not these oldest pains finally become | more fruitful for us? Is it not time that, loving, we | free ourselves from the beloved and endure, trembling, | as the arrow endures the bow, tightened in the leap, | to be more than itself? For staying is nowhere'; my translation.

See Francesco Giusti, 'Reversion: Lyric Time(s) II', in Re-: An Errant Glossary, ed. by Christoph F. E. Holzhey and Arnd Wedemeyer (Berlin: ICI Berlin, 2019), pp. 151-61 <https: //doi.org/10.25620/ci-15_19>.

31 See Walter Benjamin, 'Notes from Svendborg, Summer 1934', trans. by Rodney Livingstone, in his Selected Writings, Ir.2: 1931-1934, ed. by Michael W. Jennings, Howard Eiland, and Gary Smith (1999), pp. 78391 (pp. 783-84). 
fall of 1938 and March 1939 and partially published in the Schweizer Zeitung am Sonntag (April 1939), Benjamin engages with a sonnet by Brecht, 'Über die Gedichte des Dante auf die Beatrice' (On Dante's Poems to Beatrice):

Noch immer über der verstaubten Gruft

In der sie liegt, die er nicht vögeln durfte So oft er auch um ihre Wege schlurfte Erschüttert doch ihr Name uns die Luft.

Denn er befahl uns, ihrer zu gedenken Indem er auf sie solche Verse schrieb $\mathrm{Da}$ uns fürwahr nichts anderes übrig blieb Als seinem schönen Lob Gehör zu schenken.

Ach, welche Unsitt bracht er da in Schwang! Als er mit so gewaltigem Lobe lobte Was er nur angesehen, nicht erprobte!

Seit dieser schon beim bloßen Anblick sang Gilt, was hübsch aussieht und die Straße quert Und was nie naß wird, als begehrenswert. ${ }^{32}$

This sonnet problematizes exactly the traditional lyric gesture of praise that Rilke had retrieved from the past as a possibility for poets and for the formation of a choral 'we'. Past gestures need to be recognized and evaluated in the light of the conditions of the present in order to assess

32 'Even today, above the dusty crypt | In which she lies-the woman he could never screw | No matter how often he trailed after her- | For us, her name still makes the air tremble. $\|$ For he commanded us to remember her | By writing such poems about her | That we in truth had no choice | But to lend an ear to his beautiful praise. || Alas, what a bad habit he brought into vogue! | By praising with such mighty praise | What he had merely seen and had not tried! || Since he sang after just a glimpse | Whatever looks pretty and crosses the street | Without getting wet, passes for something to be coveted', in Walter Benjamin, 'Commentary on Poems by Brecht', trans. by Edmund Jephcott, in his Selected Writings, Iv, pp. 215-50 (pp. 237-38). Yet, one could suppose that the present does not need to be considered as a unitary context and that different situations in the present could allow for the viability of different gestures. 
their viability, but as Benjamin observes, those gestures are tested in a form transmitted from the past. The form of the sonnet helps to 'prove' the extent to which gestures and the values with which they have traditionally been associated are, or are no longer, viable in the present.

Relevant in this context is Daniel Tiffany's distinction between the generality of form, which cannot be forged, and the indexicality of diction, which points to social identities: 'One could no more fake the form of a sonnet than produce a forgery of the number 2. Only the style and diction of a particular sonnet - which possesses specific personal and social characteristics - can be faked. 33 Thinking of Giacomo's 'Madonna, dir vo voglio' and Heaney's 'Anything Can Happen', one could wonder if the iterable gestures re-enacted in those poems could function as a medium between the 'potency as an index of social identities and desires ${ }^{34}$ that pertains to diction - pointing both to contemporary reality and back to the past - and the abstract generality of form, this way allowing for the transcontextual repeatability of those poems. Brecht retrieves the form of the sonnet, but breaks the traditional, now stereotypical diction with a popular, even vulgar, style, to mockingly contest the gesture of praise for a distant beloved authoritatively transmitted by Dante's poetry. Yet, there is still something captivating about this gesture, which implies a specific kind of desire.

Giorgio Agamben detects two different ontologies in the Western tradition: the ontology of the indicative or apophantic assertion and the ontology of the imperative or non-apophantic speech. According to the Aristotelian distinction in the De interpretatione (17a 1-7) to which

33 Tiffany, 'Lyric Poetry and Poetics'.
34 Ibid. 
Agamben attends, non-apophantic is that speech which cannot be said to be true or false, because it does not manifest the being or not being of something in this world. ${ }^{35}$ Command, prayer, exhortation, and possibly praise, so widespread in lyric poetry, belong to this type of speech. Indeed, as Ramazani remarks,

As speech acts directed to an other, yet an other more veiled than a human interlocutor, poetry and prayer function simultaneously as acts of address, albeit partly suspended (hence address modulating into apostrophe), and as forms of meta-address, or images of voicing, because of the decontextualization of address from normal lines of human communication. ${ }^{36}$

Agamben identifies the command with the performative in J. L. Austin's sense of the word. ${ }^{37}$ But at this point, it is helpful to introduce a distinction advanced by Culler between performativity in Austin's sense and performance as an enunciation that exposes only itself and that, in the lyric, finds a central rhetorical device in apostrophe. ${ }^{38}$ Prayer, exhortation, and praise belong to this category of performance, which does not actualize something external to its enunciation, but exposes only itself and remains waiting in

35 Giorgio Agamben, 'Che cos'è un comando?', in his Creazione e anarchia. L'opera nell'età della religione capitalista (Vicenza: Neri Pozza, 2017), pp. 91-112.

36 Ramazani, Poetry and its Others, pp. 128-29.

37 J. L. Austin, How to Do Things with Words (Cambridge, MA: Harvard University Press, 1975).

38 Culler, Theory of the Lyric, pp. 125-31 and, on apostrophe, pp. 211-43. See also Jonathan Culler, 'Apostrophe', in The Pursuit of Signs: Semiotics, Literature, Deconstruction, 2nd edn (London: Routledge, 2001), pp. 149-71; Paul de Man, 'Lyrical Voice in Contemporary Theory', in Lyric Poetry: Beyond New Criticism, ed. by Chaviva Hošek and Patricia Parker (Ithaca, NY: Cornell University Press, 1985), pp. 55-72; William Waters, Poetry's Touch: On Lyric Address (Ithaca, NY: Cornell University Press, 2003). 
its openness. Never reaching the ultimate limit of its actualization in an accomplished act, as in the performative, nor the limit of truth or falsity with respect to the state of things in the world, as in apophantic speech, prayer, exhortation, and celebration offer themselves to re-enactment as language that finds its realization only in its re-enunciation. In this sense, Culler is right in affirming that the lyric functions as a memorable language available for repetition in different contexts and as a potential vehicle for a variety of meanings. ${ }^{39}$ Perhaps not only memorable verbal formulations but also certain selected gestures - such as the gesture of praise which Rilke re-proposes and Brecht condemns (but probably its historical dubiousness was already implicit in Rilke's exhortation) - can reach the status of lyric 'cliché, and maybe even of 'poetic kitsch' as described by Tiffany. ${ }^{40}$

The lyric, therefore, would be an enunciation that does not actualize anything but itself. From its utterance, one cannot know if the prayer, exhortation, or command will be heard, obeyed, and executed. It can only solicit a response from the external world; it establishes a relation between language and world that is held in suspension in

39 Culler, Theory of the Lyric, pp. 336-48.

40 Baudelaire's ambition to create a cliché is discussed in Daniel Tiffany, My Silver Planet: A Secret History of Poetry and Kitsch (Baltimore, MD: Johns Hopkins University Press, 2014), pp. 23-24. Culler, too, refers to Baudelaire's contention arguing that the highest success for the memorability of lyric language is to become a cliché, Culler, Theory of the Lyric, p. 131. In My Silver Planet, Tiffany explores the functions and potentialities of 'poetic kitsch' in connection with diction for the formation of a common language and collective experience. With respect to the link between 'poetic kitsch' and 'minor literature', it is interesting that, in his elegy, Rilke mentions the Italian Petrarchist poet Gaspara Stampa as a precursor, instead of Petrarch or Dante's 'style of praise', although he had been considering translating Dante's Vita nova and eventually renounced doing so just before starting writing the first elegy, see Giusti, 'Reversion'. 
its potentiality. ${ }^{41}$ This suspended relationship, which underlies lyric speech, calls for an external world in which to take place and the repetition of its performance in the attempt to bring it forth. In such language re-enacted in its pure mediality, an idea of gestural communities can be envisioned: communities based on the shareability of gestures, not on reciprocal identification among individuated subjects nor on communal knowledge nor on identical responses to literary works. This process of community formation based on the transferability (or quotability to use Benjamin's term) of certain gestures may allow us to think of the transcontextual dimension of literary texts differently. ${ }^{42}$ This kind of gesture, in fact, comes before the production of any contextual meaning and before the fulfilment of the utterance's referentiality; its transference, therefore, does not necessarily require the translatability of meaning.

In the encounter of a reader (and potential future writer) with a lyric poem, what Attridge aptly dubs an act-event, the process of individuation is counteracted by a process of dis-individuation. While reading, 'I' come to inhabit the open position of the poem's speaker making the utterance my own, but at the same time, 'I' inscribe myself into a recurrent gesture, into a transindividual medium. I have been suggesting that the most basic lyric gesture is deixis, an open deixis that never fills the gap it points to with a fixed 'now', 'this', or 'that'. One could advance the hypothesis that it bears similarities with Agamben's no-

41 Francesco Giusti, 'Temporalità liriche. Ripetizione e incompiutezza tra Dante e Caproni, Montale e Sanguineti', California Italian Studies 8.1 (2018) <https://escholarship.org/uc/item/87x199p7> [accessed 23 May 2020].

42 Perhaps also of the transtemporal co-agency of texts as explored in Rita Felski, The Limits of Critique (Chicago: University of Chicago Press, 2015), pp. 151-85. 
tion of gesture, a type of action in which 'nothing is being produced or acted, but rather something is being endured and supported. ${ }^{43}$ This gesture is neither a means to an end nor an end in itself. As dance would be gesture 'because it is nothing more than the endurance and the exhibition of the media character of corporal movements', ${ }^{44}$ the lyric might be gesture because it might be nothing more than the endurance and the exhibition of the media character of linguistic movements.

When one looks at the lyric transhistorically and subtracts contextual functions and meanings from poems, what is left to be handed over to readers and future writers is the pure mediality of certain gestures that the lyric use of language exposes primarily through its open referentiality. Such language with no ends nor functions, which calls for a world without creating it but rather holding ontology in suspension, provides a sort of shareable linguistic present for readers across different epochs and places. Readers can inscribe themselves into this present by re-enacting the poem. Two different poems as cultural artefacts or two events of the same poem as acts of reading can be connected based on the 'disappropriated', and for this reason common, presence of the medium itself. What the lyric has to offer, when readers voice its words or poets rewrite previous poems, is a shareable position with no fixed individual identities.

If Rilke exhorts 'us' to welcome and re-perform the gesture of praise, Brecht subjects it to ironic criticism, but he too must acknowledge its endurance. In fact, as Brecht

43 Giorgio Agamben, 'Notes on Gesture', in his Means without End: Notes on Politics, trans. by Vincenzo Binetti and Cesare Casarino (Minneapolis: University of Minnesota Press, 2000), pp. 49-61 (p. 56).

44 Ibid., p. 57. 
makes clear with respect to Dante's poetry, 'uns fürwahr nichts anderes übrig blieb | Als seinem schönen Lob Gehör zu schenken' (we in truth had no choice | But to lend an ear to his beautiful praise; 11. 7-8). Readers can decide how to respond - whether to make those words their own or refuse to do so - only insofar as they are called upon to respond. When readers inhabit that space by uttering the poem in their own present, they find themselves participating in a gestural community - a rather demanding position. Something similar could be said about the transnational character of poetic 'mourning' explored by Ramazani, which can be and has often been exploited for nationalist purposes. ${ }^{45}$ Our decision on the level of meaning - about the meaning of the poem but also of the community in which we find ourselves - is predicated upon the sharing of that transcontextual gesture that first constitutes us as a 'we' and puts us in common. ${ }^{46}$

Investigations in world literature often have to take the transcultural applicability of the notion of 'literature' for granted. This procedure may be understandable when engaging with contemporary literary production in a globalizing world, but proves problematic when deployed in or across different epochs. Therefore, it may be helpful to observe how recurrent gestures are presented by texts, before they acquire context-based values and functions that

45 Ramazani, A Transnational Poetics, pp. 71-93.

46 Interesting here is Eric Hayot's use of the term 'gestural' to describe the process of 'worlding': 'Worlding is gestural; it is an attitude, by which one adjusts oneself, symmetrically, to one's inclusion in a whole that does not belong to one. Worlding creates worlds because it bespeaks the part's relation to the whole, but also because in that speaking it imagines (or recreates) the whole that opens to the part. The whole neither precedes the part, nor succeeds it'. See Eric Hayot, 'World Literature and Globalization', in The Routledge Companion to World Literature, ed. by Theo D'haen, David Damrosch, and Djelal Kadir (London: Routledge, 2012), pp. 223-31 (p. 228). 
can pertain to a significant variety of symbolic realms, from religious rituals to aesthetic objects, passing through social performance, commercial entertainment, and political protest. These realms can intersect, overlap, or mingle in a certain text, but also remain separate. Apter seems to hint at a possible solution when she explores the untranslatability of fado and saudade. ${ }^{47}$ Despite their different historical meanings, behind the web of interrelated words that Apter brings together, such as saudade, acedia, Sehnsucht, spleen, melancholia, there might be a transcultural gesture of lament for a painful separation from an unrelinquishable object of desire. These gestures are not primarily offered as meaningful actions directed to a specific goal; they come before any acquisition of contextual meaning and socio-historical purpose, and thus they are made culturally available for re-enactment in different times and places.

47 Apter, Against World Literature, pp. 137-55. 
Francesco Giusti, 'Transcontextual Gestures: A Lyric Approach to the World of Literature', in The Work of World Literature, ed. by Francesco Giusti and Benjamin Lewis Robinson, Cultural Inquiry, 19 (Berlin: ICI Berlin Press, 2021), pp. 75-103 <https: //doi.org/10.37050/ci-19_04>

\section{REFERENCES}

Agamben, Giorgio, 'Che cos'è un comando?', in his Creazione e anarchia. L'opera nell'età della religione capitalista (Vicenza: Neri Pozza, 2017), pp. 91-112 'Notes on Gesture', in his Means without End: Notes on Politics, trans. by Vincenzo Binetti and Cesare Casarino (Minneapolis: University of Minnesota Press, 2000), pp. 49-61

Antonelli, Roberto, 'Canzoniere Vaticano latino 3793', in Letteratura italiana: Le Opere, ed. by Alberto Asor Rosa, 4 vols (Turin: Einaudi, 1992-96), i: Dalle Origini al Cinquecento (1992), pp. 27-44

'L'"invenzione" del sonetto', Cultura neolatina, 47 (1987), pp. 19-59

ed., I poeti della scuola siciliana, 3 vols (Milan: Mondadori, 2008), I: Giacomo da Lentini

Apter, Emily, Against World Literature: On the Politics of Untranslatability (London: Verso, 2013)

Attridge, Derek, The Singularity of Literature (London: Routledge, 2004) <https://doi.org/10.4324/9780203420447>

- The Work of Literature (Oxford: Oxford University Press, 2015) <https: //doi.org/10.1093/acprof:oso/9780198733195.001.0001>

Austin, J. L., How to Do Things with Words (Cambridge, MA: Harvard University Press, 1975) <https://doi.org/10.1093/acprof:oso/ 9780198245537.001.0001>

Barthes, Roland, How to Live Together: Novelistic Simulations of Some Everyday Experience, trans. by Kate Briggs (New York: Columbia University Press, 2012)

Benjamin, Walter, Selected Writings, 4 vols (Cambridge, MA: Harvard University Press, 1996-2003)

'Commentary on Poems by Brecht', trans. by Edmund Jephcott, in his Selected Writings, IV: 1938-1940, ed. by Howard Eiland and Michael W. Jennings (2003), pp. 215-50

'Notes from Svendborg, Summer 1934', trans. by Rodney Livingstone, in his Selected Writings, II.2: 1931-1934, ed. by Michael W. Jennings, Howard Eiland, and Gary Smith (1999), pp. 783-91 
'What is Epic Theatre? (II)', trans. by Harry Zohn, in his Selected Writings, IV: 1938-1940, ed. by Howard Eiland and Michael W. Jennings (2003), pp. 302-09

Brugnolo, Furio, 'I siciliani e l'arte dell'imitazione: Giacomo da Lentini, Rinaldo d'Aquino e Iacopo Mostacci 'traduttori' dal provenzale', La parola del testo, 3 (1999), pp. 45-74

Culler, Jonathan, 'Apostrophe,' in Jonathan Culler, The Pursuit of Signs: Semiotics, Literature, Deconstruction, 2nd edn (London: Routledge, 2001), pp. 149-71

- Theory of the Lyric (Cambridge, MA: Harvard University Press, 2015) <https://doi.org/10.4159/9780674425781>

Damrosch, David, What Is World Literature? (Princeton, NJ: Princeton University Press, 2003) <https://doi.org/10.1515/9780691188645>

Delle Donne, Fulvio, La porta del sapere: Cultura alla corte di Federico II di Svevia (Rome: Carocci, 2019)

de Man, Paul, 'Lyrical Voice in Contemporary Theory', in Lyric Poetry: Beyond New Criticism, ed. by Chaviva Hošek and Patricia Parker (Ithaca, NY: Cornell University Press, 1985), pp. 55-72

Felski, Rita, The Limits of Critique (Chicago: University of Chicago Press, 2015) <https://doi.org/10.7208/chicago/9780226294179.001.0001>

Folchetto di Marsiglia, Le poesie di Folchetto di Marsiglia, ed. by Paolo Squillacioti (Pisa: Pacini, 1999)

Giusti, Francesco, 'Literature at Work: A Conversation with Derek Attridge', Los Angeles Review of Books, 11 June 2018 <https://lareviewofbooks. org/article/literature-at-work-a-conversation-with-derek-attridge/> [accessed 23 May 2020]

_ 'Reversion: Lyric Time(s) II', in Re-: An Errant Glossary, ed. by Christoph F. E. Holzhey and Arnd Wedemeyer (Berlin: ICI Berlin, 2019), pp. 151$61<$ https://doi.org/10.25620/ci-15_19>

'Temporalità liriche. Ripetizione e incompiutezza tra Dante e Caproni, Montale e Sanguineti', California Italian Studies, 8.1 (2018) <https:// escholarship.org/uc/item/87x199p7> [accessed 23 May 2020]

Hamilton, John T., Security: Politics, Humanity, and the Philology of Care (Princeton, NJ: Princeton University Press, 2013) <https://doi.org/10. 23943/princeton/9780691157528.001.0001>

Hayot, Eric, 'World Literature and Globalization', in The Routledge Companion to World Literature, ed. by Theo D'haen, David Damrosch, and Djelal Kadir (London: Routledge, 2012), pp. 223-31 <https://doi.org/10. 4324/9780203806494>

Heaney, Seamus, District and Circle (London: Faber, 2006)

Horace, Odes and Epodes, ed. and trans. by Niall Rudd (Cambridge, MA: Harvard University Press, 2004) <https://doi.org/10.4159/DLCL.horaceodes.2004> 
Leonardi, Lino, ed., I canzonieri della lirica italiana delle origini, 4 vols (Florence: SISMEL-Edizioni del Galluzzo, 2000), I: Il Canzoniere Vaticano

Lucretius, On the Nature of Things, trans., with introduction and notes by Martin Ferguson Smith (Indianapolis, IN: Hackett Publishing Company, 2001)

Maslov, Boris, 'Lyric Universality', in The Cambridge Companion to World Literature, ed. by Ben Etherington and Jarad Zimbler (Cambridge: Cambridge University Press, 2018), pp. 133-48 <https://doi.org/10.1017/ 9781108613354.010>

Murray, David, 'Telling the Difference: Linguistic Differentiation and Identity in Guillem de Berguedà, Giacomo da Lentini and Bonifacio Calvo', Zeitschrift für romanische Philologie, 134.2 (2018), pp. 381-403 <https: //doi.org/10.1515/zrp-2018-0024>

Picone, Michelangelo, 'Aspetti della tradizione/traduzione nei poeti siciliani', in Percorsi della lirica duecentesca. Dai siciliani alla 'Vita nova' (Fiesole: Cadmo, 2003), pp. 17-31

Puchner, Martin, The Written World: The Power of Stories to Shape People, History, and Civilization (New York: Random House, 2017)

Ramazani, Jahan, Poetry and its Others: News, Prayer, Song, and the Dialogue of Genres (Chicago: University of Chicago Press, 2014) <https://doi.org/ 10.7208/chicago/9780226083421.001.0001>

- A Transnational Poetics (Chicago: University of Chicago Press, 2009) <https://doi.org/10.7208/chicago/9780226703374.001.0001>

Rilke, Rainer Maria, Werke, ed. by Manfred Engel, Ulrich Fülleborn, Horst Nalewski, and August Stahl, 4 vols (Frankfurt a.M.: Insel, 1996), II: Gedichte 1910 bis 1926, ed. by Manfred Engel and Ulrich Fülleborn

Tiffany, Daniel, 'Lyric Poetry and Poetics', in Oxford Research Encyclopedia of Literature, 30 April 2020, Oxford University Press <https://doi.org/10. 1093/acrefore/9780190201098.013.1111>

- My Silver Planet: A Secret History of Poetry and Kitsch (Baltimore: Johns Hopkins University Press, 2014)

Waters, William, Poetry's Touch: On Lyric Address (Ithaca: Cornell University Press, 2003) <https://doi.org/10.7591/9781501717062>

Weber, Samuel, Benjamin's -abilities (Cambridge, MA: Harvard University Press, 2008) 